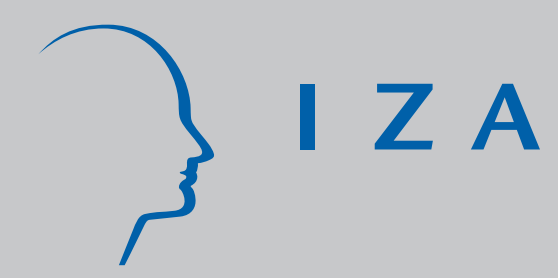

IZA DP No. 393

Union Bargaining Power: A View from J apan

Scott M. Fuess, J r.

November 2001 


\title{
Union Bargaining Power: A View from Japan
}

\author{
Scott M. Fuess, Jr. \\ Department of Economics, University of Nebraska and IZA, Bonn
}

\author{
Discussion Paper No. 393 \\ November 2001
}

\author{
IZA \\ P.O. Box 7240 \\ D-53072 Bonn \\ Germany \\ Tel.: +49-228-3894-0 \\ Fax: +49-228-3894-210 \\ Email: iza@iza.org
}

This Discussion Paper is issued within the framework of IZA's research area Internationalization of Labor Markets and European Integration. Any opinions expressed here are those of the author(s) and not those of the institute. Research disseminated by IZA may include views on policy, but the institute itself takes no institutional policy positions.

The Institute for the Study of Labor (IZA) in Bonn is a local and virtual international research center and a place of communication between science, politics and business. IZA is an independent, nonprofit limited liability company (Gesellschaft mit beschränkter Haftung) supported by the Deutsche Post AG. The center is associated with the University of Bonn and offers a stimulating research environment through its research networks, research support, and visitors and doctoral programs. IZA engages in (i) original and internationally competitive research in all fields of labor economics, (ii) development of policy concepts, and (iii) dissemination of research results and concepts to the interested public. The current research program deals with (1) mobility and flexibility of labor markets, (2) internationalization of labor markets and European integration, (3) the welfare state and labor markets, (4) labor markets in transition, (5) the future of work, (6) project evaluation and (7) general labor economics.

IZA Discussion Papers often represent preliminary work and are circulated to encourage discussion. Citation of such a paper should account for its provisional character. 
IZA Discussion Paper No. 393

November 2001

\section{ABSTRACT}

\section{Union Bargaining Power: A View from Japan*}

Industrial relations researchers have long recognized the importance of bargaining power in understanding wage settlements between labor and management. As an empirical matter it has been a challenge to develop measures of union bargaining power. Using a unique data set from Japan, this study identifies how close contract settlements came to satisfying organized labor's original demands. With those survey results over the 1960-1999 period, it is possible to develop a measure of union power and distinguish how it has fluctuated over time. These findings for Japan have important implications for empirical analysis of union bargaining power.

JEL Classification: J58, J40, J30

Keywords: Unions and collective bargaining, particular labor markets, wages

Scott M. Fuess, Jr.

Department of Economics

University of Nebraska

Lincoln, NE 68588-0489

Tel.: $+1402472-6281$

Fax: +1402 472-9700

Email: sfuess1@unl.edu

The data for this study were collected while the author was a Visiting Professor of Economics at Senshu University, Tokyo, Japan. I thank Professor Hiroshi Mochizuki of Senshu University for his assistance, especially in providing NEEDS data. Any remaining deficiencies are my responsibility. 
'Logical, internally consistent definitions of bargaining power are potentially numberless; but common sense . . . recommend[s] . . . a definition implying control || that is, power to change or maintain a price or wage rate." Lindblom (1948, p. 400)

\section{Introduction}

Industrial relations researchers have long recognized the importance of bargaining power in understanding wage settlements between labor and management. It seems obvious that the more leverage organized labor has in negotiating with employers, the more it will obtain settlements to its liking. Yet as the quotation above indicates, there are many different ways to conceptualize bargaining leverage. Beyond theoretical concerns, as an empirical matter it has been a challenge to develop measures of union bargaining power.

Details on wage settlements are often available. But how do those outcomes reflect union power? In many theoretical models, the solution for the contract wage reflects a division of the labormanagement joint-rents, with that division directly related to the union's bargaining leverage. Thus, to estimate union power researchers have tried to measure rent splitting between unions and firms. But there are many econometric difficulties associated with such an endeavor. So perhaps it is no surprise that estimates of rent sharing have varied quite widely.

To bypass the problems associated with accurately measuring rent sharing, this study takes a different approach, based on the following premise: Organized labor can be considered more powerful the closer it comes to obtaining its initial demands. There have been attempts to evaluate labor negotiations in a similar manner (Hamermesh, 1973; Bowlby and Schriver, 1978). The challenge is finding data on both settlement terms and opening demands. Press accounts often report such information for high profile negotiations in key sectors. But to assemble a systematic data set may be a considerable task. ${ }^{1}$

\footnotetext{
${ }^{1}$ Hamermesh (1973) used Bureau of National Affairs reports to compile data for 43 public sector negotiations. Bowlby and Schriver (1978) had observations from 252 different negotiations at
} 
Fortunately, Japan's Ministry of Labour has long surveyed large, unionized companies across that economy, obtaining information on both contractual pay settlements and unions' original demands. With those survey results over the 1960-1999 period, it is possible to measure how close organized labor came to its initial objectives.

Observers of Japanese industrial relations often have touted the stability of the country's "consensus-based" industrial relations. But do stable labor relations mean steady union bargaining power? It also has been suggested that Japan's company-based unions are relatively weak. With survey data covering four decades, I am able to assess union bargaining power and distinguish how it has fluctuated over time. These findings for Japan have important implications for empirical analysis of union bargaining power.

\section{Bargaining Power: Review}

Characterizing Union Bargaining Power. Early bargaining theories compared union power to that of a monopolist. ${ }^{2}$ Whereas the difference between price and marginal cost could be used to determine the extent of a monopolist's leverage, the mark-up of union pay over nonunion pay could be used to illustrate organized labor's power.

Others theorized that power is simply the ability of one party to inflict its will on another party (for example, Pen, 1952). Writers such as Slichter (1940) and Shister (1943) described bargaining power as the loss inflicted on another party relative to the cost of inflicting that loss. In a famous formulation, Chamberlain (1955, pp. 80-85) asserted that union leverage is inversely related to the cost of disagreeing with management.

Economists have continued to conceptualize union power in terms of "costs of disagreement" (Hamermesh and Rees, 1993, p. 368). Yet Svejnar (1986, p. 1057) argued that such concepts have been "too loose," that the "literature has not yet generated satisfactory measures of the elusive concepts

the Tennessee Valley Authority.

${ }^{2}$ For example, see Hicks (1932), Dunlop and Higgins (1942), and Dunlop (1944). 
of bargaining power and cost." Appealing to earlier ideas, Svejnar proposed to measure bargaining leverage by estimating union wage gains over and above the competitive market level. All that was needed was a structure for such estimations.

Bargaining Models and Estimates of Union Power. The familiar Nash asymmetric model has been used often to characterize labor settlements. In this framework wage pacts are influenced by union power, which is treated as an exogenous parameter. ${ }^{3}$ Consider a simple representation of bargaining between a union and employer. Suppose the union's surplus, $U$, can be written as

$$
U=\left(w-w_{0}\right) L,
$$

where $L$ is employment, $w$ is the wage rate under a labor contract, and $w_{0}$ is the fall-back wage received in lieu of a labor pact. The firm's surplus, $F$, is

$$
F=R(L)-w L-p_{0},
$$

where $R(L)$ is the firm's revenue function $\left(R_{L}>0, R_{L L}<0\right)$ and $p_{0}$ represents the fall-back profit. Assume the parties bargain to maximize the weighted product of their surpluses, WS:

$$
W S=U^{a} F^{1-a},
$$

with the parameter $a(0 \# a \# 1)$ representing union leverage, or bargaining power.

A simple approach is to assume that the union and firm settle on $w$ to maximize the weighted surplus WS; the firm then chooses employment so that $R_{L}=w$. Such an arrangement is known as "onthe-demand curve" bargaining. It is easily shown that a more efficient outcome occurs when the parties choose contract pay $(w)$ and employment $(L)$ to maximize $W S$, so-called "efficient bargaining."

If there is efficient bargaining, then $w$ satisfies the condition $a /(1-a)=U / F$ : The contract wage divides rents according to union power. Solving this condition yields

$$
w=w_{0}+a\left[\left\{R(L)\left|w_{0} L\right| p_{0}\right\} / L\right] .
$$

The union wage rate is simply the "fall-back" wage plus a fraction $a$ of the total rents per worker. The

${ }^{3}$ See Malcomson (1987) for review and discussion. 
wage mark-up is directly related to union bargaining power. ${ }^{4}$

Ostensibly one could estimate union leverage by regressing $w$ on the fall-back wage and a measure of rents. As a proxy for rents, some researchers have suggested using company profits. Using OLS regression and a sample of labor settlements from Canada, Abowd and Lemieux (1993) reported that organized labor captured approximately a zero percent share of total rents. Teulings and Hartog (1998, pp. 168-173) recounted similar findings from other studies of the U.K. and U.S. Yet it would be hasty to conclude that labor unions have negligible power.

Regressing $w$ on measures of market wage and total rents (or company profits) creates several econometric problems. ${ }^{5}$ First, such a specification fails to account for the endogeneity of rents (profits). Second, measures of rents (profits) are quite unreliable, resulting in damaging measurement error. Third, if there is on-the-demand-curve bargaining instead of efficient bargaining, the contract wage is still directly related to union power, but wage settlements and total rents (profits) are determined simultaneously.

Trying to avoid the biases associated with simple OLS regression, Abowd and Lemieux (1993) used an instrumental variable procedure. For their sample of Canadian labor settlements, they then found that unions captured more than twenty percent of total rents. Yet in trying to circumvent one set of measurement problems, another difficulty may have been created. According to Teulings and Hartog (1998, p. 173), the instrumental variable used by Abowd and Lemieux is itself positively correlated

\footnotetext{
${ }^{4}$ The Nash modeling framework is static, for it does not model bargaining as a process of offer and counter-offer. Strategic bargaining models have been developed in which a firm and a union make alternating offers. Binmore et al. (1986) and Osborne and Rubinstein (1990) have analyzed conditions under which the Nash solution approximates a strategic bargaining perfect equilibrium. Suppose ${ }_{u}\left(?_{f}\right)$ represents the time for the union (firm) to make an offer. Then the union's bargaining power is given by $a=?_{f} /\left(?_{u}+?_{f}\right)$ and the Nash solution approximates a dynamic equilibrium. Similarly, if $?_{u}\left(?_{f}\right)$ reflects the union's (firm's) perception of the probability of a breakdown in negotiations, then union power still follows the formula $a=$ $?_{f} /\left(?_{u}+?_{f}\right)$.
}

${ }^{5}$ For discussion of the biases that plague such regressions, see Abowd and Lemieux (1993) and Teulings and Hartog (1998, pp. 163-173). 
with the fall-back wage, leading union power to be exaggerated. In what may well be an understatement, Teulings and Hartog wrote, "These measurement problems make rent sharing a tricky field for inference" (p. 173). To compound the difficulties, while theoretical models typically treat union leverage as an exogenous parameter, other researchers have characterized bargaining power as an endogenous variable determined by various market factors (for example, Mishel, 1986).

An Alternative Measure of Union Power. Whether viewed as a parameter or dependent variable, Lindblom (1948) evidently was right, bargaining power concepts seem to be numberless. But taking a cue from Lindblom || union leverage is the ability to obtain a wage objective || I propose a slightly different way to describe and measure bargaining power.

The negotiating process usually involves an alternating sequence of demands and counteroffers. At the outset of negotiations, it is common for a union to announce a wage demand. To gauge the union's power to effect a contract to its liking, one could compare the settlement wage with the union's original demand. The more leverage a union has in the bargaining, the closer the contract wage $(w)$ will be to the union's demand $(d)$. So union leverage can be indexed as $?=(w / d) \times 100$, where 0 \# ? \# 100.

To calculate? one needs observations for contract settlements and union demands. For four decades Japan's Ministry of Labour has compiled a record of average union wage demands and contract settlements at the country's leading firms. ${ }^{6}$ So it is straightforward to use ? to evaluate union power, thereby avoiding the pitfalls associated with estimating the division of rents.

\section{Union Power in Japan: Background, Data, and Sample}

Collective Bargaining in Japan: Background. Before computing union leverage, I recount how collective bargaining proceeds in Japan. This topic has been addressed in detail elsewhere, so I

${ }^{6}$ Hamermesh (1973) and Bowlby and Schriver (1978) proposed comparing both union demands and employer counter-offers with the settlement wage. The Japanese data provide only unions' initial demands, so their proposal cannot be carried out in this case. 
present only a brief overview. ${ }^{7}$

In Japan labor unions organize employees by company, not by industry or craft. ${ }^{8}$ There were 12.1 million union members in 1998, down from the 1994 peak of 12.7 million. Although the level of union membership started to fall only in the mid-1990s, the rate of unionization has fallen since the 1970s, from over one-quarter of the labor force to less than one-fifth. Despite this trend, union density has remained relatively high in sectors like manufacturing and transportation. Moreover, at large enterprises (1,000 or employees) unionization still exceeds sixty percent.

Regular, full-time employees in Japan have annual contracts. Companies begin a new fiscal year on April 1; employees' monthly pay is set for a one-year period from this date. During the winter and early spring, union representatives at each enterprise bargain with management over pay increases for the coming fiscal year. In this "Spring Wage Campaign" (shunto) concurrent bargaining occurs across the economy between individual enterprises and their unions.

At the start of the shunto process, organized labor publicizes pay demands, either through industry level federations of company unions or a national confederation (like Rengo). Industry-wide employer groups or the Federation of Employers' Associations (Nikkeiren) typically urge restraint. After general positions have been staked out in public, bargaining occurs at the enterprise level to settle employees' monthly pay. Typically, labor settlements in strategic manufacturing industries establish a pattern for other pacts to follow.

Wage Demands and Settlements: Data and Sample. The shunto process was initiated in the mid-1950s to overcome the confrontational, disruptive industrial relations that had developed after World War II (Taira, 1970, pp. 166-203). Shortly thereafter the Labor Relations Bureau of Japan's

${ }^{7}$ For collective bargaining details, see Flath (2000, pp. 309-333), Hart and Kawasaki (1999, pp. 34-61), Hashimoto (1990, pp. 53-58), Hsu (1999, pp. 268-275, 410-413), Koike (1996, pp. 195-216), and Sasajima (1993, pp. 155-166).

${ }^{8}$ In some cases employers are organized by company plant, but the overwhelming majority of unions are organized at the company level. 
Ministry of Labour initiated an annual survey to characterize contract settlements at the country's large, unionized enterprises. The survey has sampled all companies meeting the following criteria: (1) unionized, (2) at least 1,000 employees, (3) listed on the First Section of the Tokyo or Osaka Stock Exchange, and (4) market capitalization of at least ¥2 billion. Thus, the survey covers Japan’s largest and most prominent unionized firms. The number of firms meeting the sample criteria has increased over time, from approximately 160 in the 1960 s to nearly 290 at the end of the 1990 s. $^{9}$

Survey results for the 1960-1999 shunto rounds are reported by the Ministry of Labour (see "Data Appendix"). For each year's round of negotiations, there are observations for the following (all measured in yen per month): (1) average earnings per employee prior to contract settlement, (2) average increase demanded, and (3) average earnings increase agreed to in labor pacts. Using the latter two variables, I divided the average contractual pay raise by the average increase demanded to generate a time series for union leverage. To put union demands and contractual settlements in some perspective, I also computed series for the average percentage raise demanded and that actually obtained.

\section{Union Power in Japan: Empirical Evidence}

Issues to be Investigated. Many business practices in Japan focus on building consensus between parties. Firms often establish labor-management joint-consultation committees, which meet regularly to share information about corporate matters. These committees are used to promote

${ }^{9}$ Survey results released by the Ministry of Labour are in aggregate form; data for individual companies are not available. Only the approximate number of firms in the sample has been revealed; individual companies are not identified. The ministry has divulged that survey respondents come from the following industries: Food and Tobacco, Textiles, Paper and Pulp, Newspaper and Printing, Chemicals, Petroleum, Rubber, Cement, Iron and Steel, Non-ferrous Metals, Metal Working Machinery, Electrical Machinery, Shipbuilding, Railroad Vehicles, Motor Vehicles, Commerce, Land Transportation, Broadcasting and Communication, Electric Power, Gas, Government Operated Enterprises, Construction (only since 1987), and Services (only since 1987). The ministry also has made public that (1) from 1986 both Nippon Telephone and Telegraph (NTT) and Nippon Tobacco (JT) have been included in the sample and (2) for 1973-1977 results for the "Iron and Steel" companies were not included in the tabulations released. For data sources, see the "Data Appendix." 
harmony regarding all aspects of company operations, including pay. The consultation committees do not negotiate labor contracts, but the information shared is used to build consensus about pay settlements. Analyzing a survey of 97 large corporations from the 1981 shunto round, Morishima (1991a, 1991b) reported that labor settlements were reached more quickly for those companies more actively engaged in joint consultation. According to Hart and Kawasaki (1999, p. 44), contract agreements represent "sharing arrangements within a climate of mutual co-operation and moderation of self-interest."

If unions and firms have routinely achieved harmony in their wage negotiations, ? may be fairly steady over time. If consensus is realized simply by splitting their differences, we will observe $?=50$, meaning unions obtained half of the amounts demanded.

Japan's enterprise unions often have been characterized as docile. Their members include both blue-collar workers and white-collar managers. Union officials are drawn from the ranks of company employees and these officials often go on to become company executives. Taira (1970, p. 169) called the Japanese enterprise union "just another management in the firm." Because they are sympathetic to managerial objectives, unions are alleged to be weak (Koike, 1996, p. 195). If enterprise unions are not keen to press their demands, it would be typical to observe $?<50$. If union leverage eroded along with the decline in union density, then ? should fall for the latter years of the sample.

Given the issues discussed above, I wish to determine whether union bargaining leverage was steady or fluctuated over the years. Furthermore, I wish to identify whether or not unions typically came close to their bargaining objectives.

Union Bargaining Power. Table 1 presents union bargaining power (?) for each year of the 1960-1999 sample. The table also shows the average increase (as a percentage) demanded and that actually obtained. Both the average raise sought and pay hike actually obtained fluctuated greatly. Likewise union bargaining leverage could vary substantially from year to year. 
Sometimes unions obtained 80 percent or more of the wages demanded (maximum ?, 82.4); in other years they secured as little as 40 percent (minimum ?, 40.8). Nine times ? swerves more than 10 points from one year to the next. In fact, the extreme measures for union leverage occur for consecutive years, 1974 (maximum) and 1975 (minimum). Such swings shed some light about "consensus" in Japanese industrial relations.

To support their claim of labor relations flexibility, Hart and Kawasaki (1999) cited the aftermath of the 1974 oil shock. Because of information sharing and a cooperative climate in negotiations, "both employers and employees quickly came to realise the foolishness of wage-price spirals" (p. 44). But the data in Table 1 suggest an amendment to that view: Moderation in contractual pay occurred because unions lost bargaining power.

In the 1974 shunto talks unions pressed for 39.9 percent pay hikes and employers largely acquiesced, as indicated by the ? value of 82.4. In 1975 organized labor's demands had not moderated much, for unions still sought 32.1 percent pay hikes. Yet employers evidently resisted these demands, for? slumps to 40.8. Given unions' ongoing demands and subsequent collapse of bargaining power, it would appear that employer opposition, not mutual cooperation, helped contain contractual pay growth. It was only later in the 1970s that organized labor moderated its objectives and regained some leverage.

Looking at the figures in Table 1 more closely, union power drops every time contractual pay growth falls by at least one percentage point (nine occurrences in the sample). Apparently pay restraint was instigated by employer resistance and concurrent drop in union leverage. Conversely, union leverage improves every time pay growth accelerates by at least one point (eight occurrences). Escalating wage growth was the product of more effective union bargaining. Despite occasional setbacks, unions frequently were successful in achieving bargaining objectives. In virtually every year of the sample (thirty-six of forty), organized labor obtained more than 50 percent of its pay demands. With ? exhibiting a mean value of 64.3 , labor and management did not simply split their differences (see 
Table 2 for descriptive statistics). For eighteen of the forty years, in fact, the power measure exceeds two-thirds. Moreover, union power did not decline systematically along with the drop in union density. Whenever union leverage was greatest, ? > 70, labor had just accelerated its demands from the year before. Nevertheless, escalating demands do not always coincide with escalation of union power. There are nine years for which the average raise sought was at least one percentage point greater than the year before, yet for three of them ? is lower than the prior year. Whenever unions were at their weakest, ? $<50$, they had just softened their demands from the previous year. Yet more modest objectives generally do not correspond with erosion of union leverage. There are thirteen occurrences for which the raise sought was at least one percentage point lower than the year before; seven of those times ? is actually higher than the year before. For these years of moderate demands, ? averages roughly 59 percent, only five points below the mean value for the entire sample.

Much of the time union objectives were relatively stable; that is, raises sought were within one percentage point of the previous year's demand. For these years the mean value of ? is 65 percent, virtually identical to the mean for the whole sample.

Although union bargaining leverage can fluctuate from year to year, sometimes quite dramatically, it seems as if there is a "consensus" about a long-term benchmark: Organized labor gets roughly 65 percent of the pay hikes demanded. Accordingly, labor unions in Japan cannot be viewed as consistently weak. Unions have been strong enough to obtain regularly contract settlements that meet their demands more than halfway.

Union Power and the Economy's Performance. Japan's economy passed through different phases over the sample period. For a clearer idea how bargaining power varies, consider the descriptive statistics presented in Table 2.

Between the 1960 and 1973 shunto rounds the economy experienced rapid expansion; real growth averaged 9.8 percent yearly with 5.6 percent inflation. Meanwhile, organized labor demanded hefty raises of 21.2 percent per year, settling for increases of 13.5 percent. So during this phase of fast-paced growth, union power exhibits a mean value of 63.1 (standard deviation, 10.6), almost the 
same for the whole sample.

Japan was jolted by oil shocks between the 1974 and 1981 labor talks, resulting in slower growth (4 percent annually) and higher inflation (8.5 percent). Considering the economic slow-down, organized labor continued to press for substantial pay hikes (18.2 percent annually). Yet despite the big drop in 1975, ? still averages 62.2, close to the mark for the years of rapid expansion.

For the next ten years annual economic growth continued to average 4 percent, but with much lower inflation (under 2 percent per year). Now unions tempered their objectives and their leverage recovered; ? averages 68.3 for the 1982-1991 shunto rounds (varying much less than before).

In the late 1980s Japan experienced an episode now known as the "bubble economy." Speculative increases in real estate and share prices fueled an economy-wide binge of lending and spending. Since the speculative bubble burst in late 1990 the economy has endured prolonged sluggishness. Between the 1992 and 1995 labor talks economic growth averaged only 1.4 percent, with 1.3 percent inflation. Compared to the 1980s, unions scaled back their demands somewhat, seeking yearly pay hikes of 6.3 percent instead of 7.3 percent. Union power suffered: ? averages only 58.8 (with barely any fluctuation).

Between the 1996 and 1999 labor talks economic growth still averaged 1.4 percent, but inflation fell to -0.4 percent. Compared to the early "post-bubble" years, unions scaled back their objectives more substantially (seeking 4 percent pay growth). Now as organized labor tempered its demands, bargaining power rebounded, with ? rising to an average of 67.8 .

Not surprisingly, it looks as if union power in Japan is related to the economy's overall performance, to factors like economic growth or inflation. I used OLS regression to estimate simple equations for pay hikes demanded, contractual pay raises, and union bargaining leverage. Table 3 presents the regression estimates. As shown in the first two columns of the table, both union demands and contractual pay growth are directly related to real GDP growth and inflation.

Higher inflation adds significantly to union demands. A 1 point acceleration in inflation leads organized labor to escalate the demanded pay raise by 1 point too. But contractual pay growth 
improves only 0.5 points, meaning unions lose bargaining leverage as inflation accelerates. In the right column of Table 3 , it can be confirmed that a 1 point increase in inflation subtracts 0.97 points from the measure of union power.

Unions also lose leverage when the economy slows down. Cutting GDP growth prompts organized labor to restrain its objectives, cutting 0.6 points from pay hikes demanded. But contractual pay growth falls even more, by 0.9 points, meaning union leverage falls as GDP growth slows. Indeed, the right column of Table 3 reveals that a 1 point decline in GDP growth subtracts nearly 1.2 points from the measure of union leverage.

\section{Summary and Concluding Remarks}

This study has proposed a simple measure of union bargaining power, comparing contractual outcomes with unions' initial demands. With observations for 1960-1999 from Japan's largest unionized companies, there are some important findings about organized labor's bargaining leverage.

It has been alleged that labor unions in Japan are relatively docile, meekly submitting to managerial objectives. That impression is misleading, for organized labor consistently has been able to secure its pay demands more than halfway. Furthermore, company unions have been quite willing to press for aggressive pay hikes. Frequently unions accelerated demands from the previous year and were able to realize increased bargaining leverage.

Harmonious labor relations allegedly have resulted in "consensus" about appropriate pay settlements, meaning contractual wage flexibility. This view should be modified. It is true that contractual pay in Japan has been flexible. But restraint of pay growth has occurred because unions were not able to obtain their demands, that is, because unions lost bargaining leverage with firms. Similarly, acceleration of pay growth corresponds with improvements in union bargaining leverage.

If there was consistent labor-management consensus about room to increase pay, then union bargaining power should have been relatively stable. This study shows that bargaining power has fluctuated significantly. Both higher inflation and slower economic growth serve to erode organized 
labor's leverage. Nevertheless there does appear to be a long-term benchmark, a long-term "consensus," about labor settlements in Japan. Despite year-to-year fluctuations, there is a long-term trend for organized labor to obtain roughly 65 percent of the pay hikes demanded. The findings of this study should be of interest to scholars of Japan's economy and its labor relations. But they are also relevant beyond Japan. My measure of union power bypasses the econometric difficulties associated with the estimation of rent sharing. Some past studies have analyzed contract outcomes relative to opening demands. I expect students of bargaining power will find it worthwhile to assemble information on union wages and demands. For then it will be comparatively straightforward to assess union power and analyze its determinants.

The fluctuations I document for Japan indicate that union power should not be treated as an exogenous parameter. Any efforts to estimate rent sharing must account for the endogenous nature of bargaining power. There are implications for theoretical models too. Factors that affect bargaining leverage (like economic growth) also can alter the size of the joint-rents divided by labor and management. Therefore, I would expect future research to try to identify and assess distinct "surplus" and "power" effects in the bargaining between unions and employers. 


\section{Data Appendix}

Union Demands and Contractual Pay. Survey results for the 1960-1999 shunto rounds are available from the Ministry of Labour's Year Book of Labour Statistics. For each year's round of negotiations, there are observations for the following (all measured in yen per month):

(1) average earnings per employee prior to contract settlement ("Wages prior to wageincrease"),

(2) average increase demanded ("Wages for demand"), and

(3) average earnings increase agreed to in labor pacts ("Amount of wage-increase"). Using the latter two variables, I divided the average contractual increase by the average raise demanded to compute ?. I also computed series for the average percentage raise demanded and that actually obtained. All three series are reported in Table 1. The exact citation for the data is as follows: Ministry of Labour, Minister's Secretariat, Policy Planning and Research Department, Year Book of Labour Statistics, Tokyo, Ministry of Labour. The data were published in a table bearing the legend "The status of springtime wage-increase" or "Conditions relating to spring wage increase (shunto)." I obtained data from the following Year Books: 1998 (Table 122), 1997 (Table 133), 1996 (Table 117), 1994 (Table 137), 1993 (Table 111), 1990 (Table 115), 1985 (Table 96), 1979 (Table 103), and 1978 (Table 117).

Economic Growth and Inflation. Annual observations for real GDP (measured in 1990 yen) and the GDP deflator are from the Nikkei NEEDS Data Base. With these data, I computed real GDP growth; I also calculated the annual change in the GDP deflator, which I used to represent the inflation rate. The GDP data were provided to the author by Hiroshi Mochizuki, June 2000. 


\section{References}

Abowd, John A. and Thomas Lemieux. 1993. “The Effects of Product Market Competition on Collective Bargaining Agreements: The Case of Foreign Competition in Canada." Quarterly Journal of Economics 108 (November): 983-1014.

Binmore, Kenneth, Ariel Rubinstein, and A. Wolinsky. 1986. “The Nash Bargaining Solution in Economic Modelling.” Rand Journal of Economics 17 (Summer): 176-188.

Bowlby, Roger L. and William R. Schriver. 1978. "Bluffing and the 'Split-the-Difference' Theory of Wage Bargaining." Industrial and Labor Relations Review (January): $161-171$

Chamberlain, Neil W. 1955. A General Theory of Economic Process. New York: Harper and Row.

Dunlop, John T. 1944. Wage Determination Under Trade Unions. New York: MacMillan. Dunlop, John T. and Benjamin Higgins. 1942. "“Bargaining Power' and Market Structures.” Journal of Political Economy 50 (February): 1-26.

Flath, David. 2000. The Japanese Economy. Oxford: Oxford University Press.

Hamermesh, Daniel S. 1973. “Who 'Wins' in Wage Bargaining?” Industrial and Labor Relations Review 26 (July): 1146-1149.

Hamermesh, Daniel S. and Albert Rees. 1993. The Economics of Work and Pay. Fifth edition. New York: Harper Collins.

Hart, Robert A. and Seiichi Kawasaki. 1999. Work and Pay in Japan. Cambridge, U.K.: Cambridge University Press.

Hashimoto, Masanori. 1990. The Japanese Labor Market in a Comparative Perspective with the United States. Kalamazoo, Mich.: W.E Upjohn Institute for Employment Research.

Hicks, John. 1932. The Theory of Wages. London: MacMillan.

Hsu, Robert C. 1999. The MIT Encyclopedia of the Japanese Economy. Second edition. Cambridge, Mass.: MIT Press. 
Koike, Kazuo. 1996. The Economics of Work in Japan. Tokyo: LTCB International Library Foundation.

Lindblom, Charles E. 1948. “'Bargaining Power' in Price and Wage Determination.” Quarterly Journal of Economics 62 (May): 396-417.

Ministry of Labour, Minister's Secretariat, Policy Planning and Research Department. 1999. Year Book of Labour Statistics 1998. Tokyo: Ministry of Labour.

Mishel, Lawrence. 1986. "The Structural Determinants of Union Bargaining Power.” Industrial and Labor Relations Review 40 (October): 90-104.

Malcomson, James M. 1987. “Trade Union Labour Contracts: An Introduction.” European Economic Review 31 (February-March): 139-148.

Morishima, Motohiro. 1991a. "Information Sharing and Collective Bargaining in Japan: Effects on Wage Negotiation." Industrial and Labor Relations Review 44 (April): 469-487. . 1991b. "Information Sharing and Firm Performance in Japan." Industrial Relations 30 (Winter): 37-61.

Osborne, Martin J. and Ariel Rubinstein. 1990. Bargaining and Markets. San Diego: Academic Press.

Pen, J. 1952. “A General Theory of Bargaining.” American Economic Review 42 (March): 24-42.

Sasajima, Yoshio. 1993. “The Japanese Labour Market: Its Institutions and Performance.” In Labour Market Contracts and Institutions, edited by Joop Hartog and Jules Theeuwes, pp. 151-184. Amsterdam: North-Holland.

Shister, Joseph. 1943. "The Theory of Union Bargaining Power." Southern Economic Journal 10 (October): 151-159.

Slichter, Sumner H. 1940. "The Impact of Social Security Legislation Upon Mobility and Enterprise.” American Economic Review 30 (March): 44-60. 
Svejnar, Jan. 1986. "Bargaining Power, Fear of Disagreement, and Wage Settlements: Theory and Evidence from U.S. Industry.” Econometrica 54 (September): 1055-1078.

Taira, Koji. 1970. Economic Development \& the Labor Market in Japan. New York: Columbia University Press.

Teulings, Coen and Joop Hartog. 1998. Corporatism or Competition? Cambridge, U.K.: Cambridge University Press. 
Table 1

Union Demands, Actual raises, and Bargaining Power: 1960-1999*

\begin{tabular}{|c|c|c|c|c|c|c|c|c|}
\hline Year & $\begin{array}{c}\text { Raise } \\
\text { Demanded }\end{array}$ & $\begin{array}{c}\text { Actual } \\
\text { Raise }\end{array}$ & $\begin{array}{l}\text { Union } \\
\text { Power (?) }\end{array}$ & $\begin{array}{l}* \\
*\end{array}$ & Year & $\begin{array}{c}\text { Raise } \\
\text { Demanded }\end{array}$ & $\begin{array}{c}\text { Actual } \\
\text { Raise }\end{array}$ & $\begin{array}{l}\text { Union } \\
\text { Power (?) }\end{array}$ \\
\hline 1960 & $13.79 \%$ & $8.73 \%$ & $63.30 \%$ & $\begin{array}{l}* \\
* \\
*\end{array}$ & 1980 & $8.75 \%$ & $6.74 \%$ & $77.05 \%$ \\
\hline 1961 & 18.85 & 13.85 & 73.46 & $\begin{array}{l}* \\
*\end{array}$ & 1981 & 10.26 & 7.68 & 74.92 \\
\hline 1962 & 21.21 & 10.66 & 50.26 & $\begin{array}{l}* \\
*\end{array}$ & 1982 & 9.31 & 7.01 & 75.29 \\
\hline 1963 & 19.48 & 9.05 & 46.46 & $\begin{array}{l}* \\
*\end{array}$ & 1983 & 7.37 & 4.40 & 59.75 \\
\hline 1964 & 20.84 & 12.41 & 59.57 & $\begin{array}{l}* \\
*\end{array}$ & 1984 & 6.50 & 4.46 & 68.70 \\
\hline 1965 & 20.97 & 10.63 & 50.69 & $\begin{array}{l}* \\
*\end{array}$ & 1985 & 7.18 & 5.03 & 70.10 \\
\hline 1966 & 20.64 & 10.60 & 51.38 & $\begin{array}{l}* \\
*\end{array}$ & 1986 & 7.35 & 4.55 & 61.90 \\
\hline 1967 & 20.05 & 12.48 & 62.22 & $\begin{array}{l}* \\
*\end{array}$ & 1987 & 5.54 & 3.56 & 64.34 \\
\hline 1968 & 21.86 & 13.94 & 63.77 & $\begin{array}{l}* \\
*\end{array}$ & 1988 & 6.54 & 4.43 & 67.77 \\
\hline 1969 & 22.70 & 15.84 & 69.77 & $\begin{array}{l}* \\
*\end{array}$ & 1989 & 7.07 & 5.17 & 73.13 \\
\hline 1970 & 23.83 & 18.52 & 77.71 & $\begin{array}{l}* \\
*\end{array}$ & 1990 & 8.20 & 5.94 & 72.49 \\
\hline 1971 & 24.35 & 16.93 & 69.52 & $\begin{array}{l}* \\
*\end{array}$ & 1991 & 8.16 & 5.65 & 69.17 \\
\hline 1972 & 23.30 & 15.30 & 65.69 & $\begin{array}{l}* \\
*\end{array}$ & 1992 & 7.95 & 4.95 & 62.22 \\
\hline 1973 & 25.05 & 20.09 & 80.22 & $\begin{array}{l}* \\
*\end{array}$ & 1993 & 7.07 & 3.89 & 55.12 \\
\hline 1974 & 39.88 & 32.85 & 82.39 & $\begin{array}{l}* \\
*\end{array}$ & 1994 & 5.30 & 3.13 & 58.94 \\
\hline 1975 & 32.07 & 13.08 & 40.80 & $\begin{array}{l}* \\
*\end{array}$ & 1995 & 4.80 & 2.83 & 58.91 \\
\hline 1976 & 18.11 & 8.83 & 48.74 & $\begin{array}{l}* \\
*\end{array}$ & 1996 & 4.32 & 2.86 & 66.06 \\
\hline 1977 & 15.50 & 8.76 & 56.52 & $\begin{array}{l}* \\
*\end{array}$ & 1997 & 4.15 & 2.90 & 69.82 \\
\hline 1978 & 12.53 & 5.89 & 46.98 & $\begin{array}{l}* \\
*\end{array}$ & 1998 & 4.40 & 2.66 & 60.44 \\
\hline 1979 & 8.30 & 5.83 & 70.28 & $\begin{array}{l}* \\
*\end{array}$ & 1999 & 2.95 & 2.21 & 74.98 \\
\hline
\end{tabular}

*For sources, see "Data Appendix." 
Table 2

Union Demands, Actual Raises, and Bargaining Power: Descriptive Statistics*

\begin{tabular}{lccc}
\hline & $\begin{array}{c}\text { Raise } \\
\text { Demanded }\end{array}$ & $\begin{array}{c}\text { Actual } \\
\text { Raise }\end{array}$ & $\begin{array}{c}\text { Union } \\
\text { Power (?) }\end{array}$ \\
Years: 1960-1999 & $13.91 \%$ & $8.86 \%$ & $64.27 \%$ \\
Mean & 8.81 & 6.20 & 10.07 \\
Standard Deviation & & & \\
\hline
\end{tabular}

Years: $1960-1973$

\begin{tabular}{|c|c|c|}
\hline Mean & $21.21 \%$ & $13.50 \%$ \\
\hline
\end{tabular}

$\begin{array}{lll}\text { Standard Deviation } & 2.83 & 3.50\end{array}$

Years: 1974-1981

$\begin{array}{llll}\text { Mean } & 18.17 \% & 11.21 \% & 62.21 \%\end{array}$

$\begin{array}{lll}\text { Standard Deviation } & 11.66 & 9.05\end{array}$

Years: 1982-1991

$\begin{array}{llll}\text { Mean } & 7.32 \% & 5.02 \% & 68.27 \%\end{array}$

$\begin{array}{llll}\text { Standard Deviation } & 1.05 & 0.98 & 4.99\end{array}$

Years: 1992-1995

$\begin{array}{llll}\text { Mean } & 6.27 \% & 3.70 \% & 58.80 \%\end{array}$

$\begin{array}{llll}\text { Standard Deviation } & 1.48 & 0.94 & 2.91\end{array}$

Years: 1996-1999

$\begin{array}{llll}\text { Mean } & 3.96 \% & 2.66 \% & 67.83 \%\end{array}$

$\begin{array}{llll}\text { Standard Deviation } & 0.68 & 0.31 & 6.13\end{array}$

*For sources, see "Data Appendix." 
Table 3

Union Bargaining Power and Economic Conditions Overall: OLS Regression

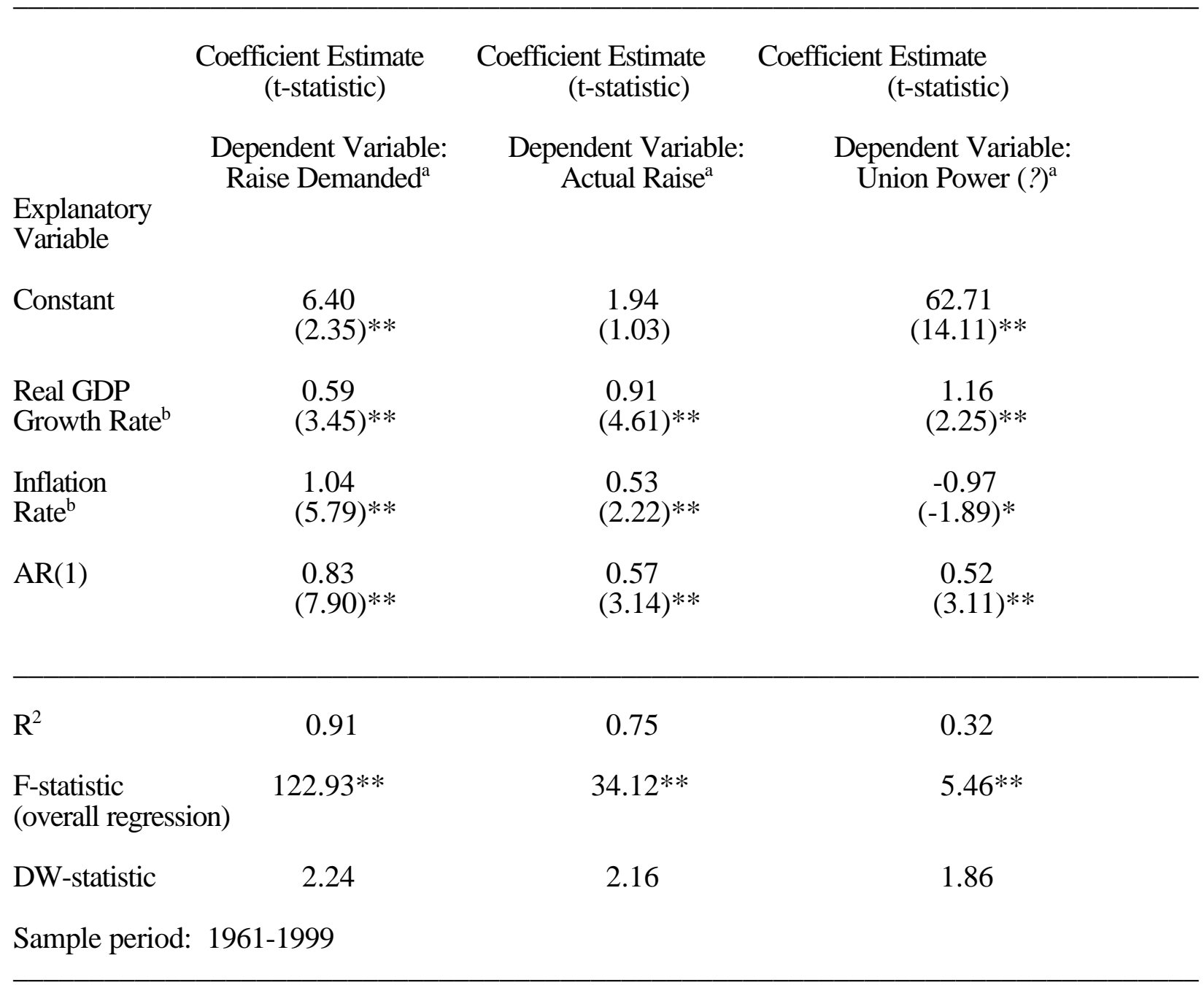

"For data sources, see "Data Appendix."

${ }^{\mathrm{b}}$ Because collective bargaining occurs in the opening months of year $t$, I use as explanatory

variables the growth rate and inflation rate from the recently completed year $t-1$. For sources, see

"Data Appendix." 


\section{IZA Discussion Papers}

No. Author(s)

379

380

381

382

383

384

385

386

387

388

389

390

391

392
H. Antecol

D. A. Cobb-Clark

M. Sattinger

J. T. Addison

P. Teixeira

L. Goerke

D. Blau

E. Tekin

D. Acemoglu

J.-S. Pischke

A. Ichino

R. T. Riphahn

J. Wagner

C. Schnabel

A. Kölling

C. Grund

D. Sliwka

L. Farrell

M. A. Shields

T. Beissinger

H. Egger

T. Beissinger

J. T. Addison

P. Teixeira

P. Tsakloglou

F. Papadopoulos
Title

Area

Date

The Sexual Harassment of Female Active-Duty

5

$10 / 01$

Personnel: Effects on Job Satisfaction and Intentions to Remain in the Military

A Kaldor Matching Model of Real Wage

7

$10 / 01$

Declines

The Economics of Employment Protection

3

$10 / 01$

Tax Evasion in a Unionised Economy

3

$11 / 01$

The Determinants and Consequences of Child

3

$11 / 01$

Care Subsidies for Single Mothers

Minimum Wages and On-the-Job Training

$11 / 01$

The Effect of Employment Protection on Worker

$11 / 01$

Effort: A Comparison of Absenteeism During and After Probation

Threshold Values in German Labor Law and Job

3

$11 / 01$

Dynamics in Small Firms: The Case of the

Disability Law

The Impact of Wage Increases on Job

Satisfaction - Empirical Evidence and

Theoretical Implications

Child Expenditure: The Role of Working

$11 / 01$

Mothers, Lone Parents, Sibling Composition and Household Provision

Dynamic Wage Bargaining if Benefits are Tied to Individual Wages

3

$11 / 01$

The Impact of Labor Market Reforms on Capital

Flows, Wages and Unemployment

2

$11 / 01$

Employment Adjustment in Portugal: Evidence

from Aggregate and Firm Data

Identifying Population Groups at High Risk of

Social Exclusion: Evidence from the ECHP

$11 / 01$
3

1

2 